\title{
Gangguan (Disrupsi) terhadap Lembaga Partai Golkar oleh Relawan Politik dalam Pemilu 2019

\author{
Disruption to Golkar Party Institutions by Political Volunteers in The 2019 Election
}

\author{
Arifki \\ Mahasiswa Pasca Sarjana Ilmu Politik Universitas Indonesia \\ email: arifkichaniago24@gmail.com
}

\begin{tabular}{l} 
Riwayat Artikel \\
\hline Diterima: 1 Agustus 2021 \\
Direvisi: 22 Oktober 2021 \\
Disetujui: 29 Oktober 2021 \\
doi: $10.22212 /$ jp.v12i1.2484
\end{tabular}

\begin{abstract}
This paper discusses the disruption experienced by Golkar party institutions in the 2019 election. Political volunteers who were once the antithesis of political parties, in the 2019 election, Golkar party formed it from the internal party. Party organizations that work with structural approaches are different from dynamic volunteer patterns. Gojo volunteers were formed to win Jokowi in the presidential election and Golkar in parliament. Golkar's efforts to get the tail effect of Jokowi's figure is to co-branding Jokowi. The goal is that the PDI-P does not capitalize on Jokowi's image for the benefit of its party only. Jokowi's coalition-supporting party also hopes to get a position of effect from simultaneous elections. In addition, these volunteers also influenced the Golkar party's campaign pattern to make digital use and the placement of young cadres as candidates for the legislature. The disruption experienced by Golkar has a good impact with political change, namely easily Golkar accepts all political changes. The approach used in this paper is qualitative using Francis Fukuyama's concept of disruption and Samuel P. Huntington's institutionalization concept. The findings of this paper, the disruption that occurred within Golkar with the use of political volunteers in elections did not have a significant impact on Golkar's vote in parliament because legislative and presidential elections were held simultaneously, so the electoral impact was only obtained by parties that had cadres running as presidential candidates.
\end{abstract}

Keywords: Golkar; Disruption; Institutions; Volunteers

\begin{tabular}{l} 
Abstrak \\
\hline Tulisan ini membahas tentang gangguan (disrupsi) yang dialami oleh lembaga Partai \\
Golkar di Pemilu 2019. Relawan politik yang dulunya antitesis dari partai politik, di \\
Pemilu 2019, Partai Golkar membentuknya dari internal partai. Organisasi partai yang \\
bekerja dengan pendekatan struktural berbeda dengan pola relawan yang dinamis. \\
Relawan Gojo dibentuk untuk memenangkan Jokowi di Pilpres dan Golkar di parlemen. \\
Upaya Golkar untuk mendapatkan efek ekor jas dari sosok Jokowi adalah dengan \\
melakukan co-branding terhadap Jokowi. Tujuannya agar PDI-P tidak mengkapitalisasi \\
citra Jokowi untuk kepentingannya partainya saja. Partai anggota koalisi pendukung \\
Jokowi juga berharap mendapatkan posisi efek dari pemilu serentak. Selain itu, relawan \\
ini juga ikut mempengaruhi pola kampanye Partai Golkar agar melakukan pemanfaatan \\
digital dan penempatan kader-kader muda sebagai calon anggota legislatif. Disrupsi \\
yang dialami oleh Golkar berdampak baik dengan perubahan politik, yakni dengan \\
mudahnya Golkar menerima segala perubahan politik. Pendekatan yang digunakan di \\
tulisan ini kualitatif dengan mengunakan konsep disrupsi Francis Fukuyama dan konsep \\
pelembagaan Samuel P. Huntington. Temuan dari tulisan ini, disrupsi yang terjadi di \\
internal Golkar dengan pemanfaatan relawan politik dalam pemilu tidak memberikan \\
dampak yang signifikan terhadap suara Golkar di parlemen karena pemilihan legislatif \\
dan presiden dilaksanakan bersamaan, sehingga dampak elektoral hanya didapatkan \\
oleh partai yang memiliki kader yang maju sebagai calon presiden. \\
Kata kunci: Golkar; Disrupsi; Lembaga; Relawan.
\end{tabular} 


\section{Latar Belakang}

Kekuasaan Soeharto selama tiga puluh dua tahun memimpin Indonesia berasal dari jalur ABG, yaitu militer (ABRI), Birokrasi, dan Golkar. Namun pasca-reformasi, dari tiga jalur tersebut, hanya Golkar yang tetap eksis memainkan panggung utama kekuasaan. Militer dan birokrasi kembali menjadi lembaga netral yang tidak berpihak dengan kekuatan politik manapun, sedangkan Golkar berubah sebagai partai politik, namun dengan Privilege politiknya tidak lagi sama dengan era Soeharto.

Upaya yang dilakukan oleh Golkar untuk mengembalikan kejayaan adalah dengan melakukan co-branding. Golkar yang dicitrakan sebagai partainya Soeharto dihilangkan pengaruhnya dari partai pasca-turun jabatan sebagai presiden. Golkar pun mulai dikenal oleh masyarakat dengan kuatnya jaringan infrastruktur kekuasaan. Namun, pembangunan jaringan lebih terbuka ke ruang publik dengan harapan Golkar mendapatkan empati dari masyarakat.

Golkar survive di era reformasi dengan sukses memenangkan Pemilu tahun 2004. Namun, di Pilpres 2004 Golkar kalah dengan mengusung Wiranto sebagai calon presiden. Kalahnya Wiranto sebagai calon presiden, Golkar memanfaatkan kemenangan Jusuf Kalla sebagai wakil presiden untuk masuk ke pemerintahan. Kondisi yang sama terjadi di Pilpres 2009, Golkar mengusung Jusuf Kalla sebagai calon presiden. Namun hasilnya, Jusuf Kalla kalah dengan Susilo Bambang Yudhoyono (SBY). Dengan kalahnya Jusuf Kalla, Golkar kembali beradaptasi untuk masuk ke pemerintahan lewat terpilihnya Aburizal Bakrie sebagai ketua umum, yang posisinya saat itu sebagai menteri SBY.

Pemilu 2014 Golkar mendukung pasangan Prabowo-Hatta. Hasil dari pemilu ini dimenangkan oleh pasangan Jokowi-Kalla. Golkar yang tergabung ke dalam Koalisi Merah
Putih (KMP) secara tidak langsung menjadi bagian dari kelompok oposisi. Namun, sikap politik hanya berlaku sementara, setelah itu terjadi gejolak di internal Golkar dengan munculnya dualisme kepemimpinan Golkar yaitu kubu Aburizal Bakrie dan Agung Laksono. Lebih lanjut, konflik internal Golkar tersebut menjadi jalan bagi Golkar untuk bergabung ke pemerintahan Jokowi-Kalla. Menangnya Agung Laksono dalam dualisme kepemimpinan Partai Golkar, secara langsung Golkar meninggalkan Koalisi Merah Putih (KMP) yang selama ini dipimpin oleh Aburizal Bakrie.

Bergabungnya Golkar ke dalam pemerintahan Jokowi pada pergantian kabinet II, 27 Juli 2016 berdampak dengan masuknya Airlangga Hartarto sebagai Menteri Perindustrian. ${ }^{1}$ Melalui Airlangga Hartarto, Partai Golkar semakin dekat dengan Jokowi, terutama setelah terpilih sebagai Ketua Umum Golkar tahun 2017. Posisi Airlangga Hartarto sebagai menteri dan Ketua Umum Golkar memperkuat dukungan terhadap Jokowi. Sebagai lembaga politik, Golkar dengan mudah beradaptasi dengan perubahan karena merupakan partai terbuka yang tidak berpihak dengan ideologi ekstrim manapun-baik kanan atau pun kiri. Hal ini lah yang mendukung Golkar dengan mudah menyesuaikan diri dengan rezim yang sedang berkuasa dari pemilu ke pemilu. Keberagaman tokoh menyebabkan Golkar tidak khawatir dengan dinamika politik yang terjadi.

Pemilu 2019 dilaksanakan berbeda dari pemilu sebelumnya yakni pemilihan legislatif dan presiden dilaksanakan secara bersamaan. Partai yang memiliki kader yang maju sebagai calon presiden akan mendapatkan keuntungan karena masyarakat yang mengenal calon presiden diasumsikan berdampak kepada suara partai. Sistem ini bagi partai koalisi

\footnotetext{
1 Arifki Chaniago. "Split Ticket Voting." 26 Maret 2019. Diakses 29 Juni 2020. https://news.detik.com/ kolom/d-4483650/split-ticket-voting-di-pemilu-2019.
} 
pendukung calon presiden tentu merugikan karena sulit mendapatkan efek dukungan calon presiden.

Partai Golkar yang mendukung Jokowi sebagai calon presiden berharap dengan efek elektoral dari Pemilu 2019. Dengan tidak memiliki kader sebagai calon presiden dan wakil presiden Golkar memanfaatkan dukungannya terhadap Jokowi. Salah satu upaya yang dilakukan oleh Golkar adalah dengan membentuk relawan politik. Dari dua relawan politik yang dibentuk Golkar tulisan ini fokus terhadap Relawan Golkar Jokowi (Gojo). Partai Golkar menggunakan relawan di Pemilu 2019 sebagai upaya untuk mendapatkan pemilih baru.

Munculnya relawan politik lazimnya merupakan bagian dari kelompok tidak puas dengan partai politik. Relawan hadir membawa pendekatan baru dalam sistem kampanye partai politik, yang selama ini memiliki pendekatan sendiri di pemilu, sehingga kelahiran relawan politik merupakan bentuk mengubah pendekatan terhadap partai. Namun, di Pemilu 2019 Partai Golkar membentuk relawan yang didukung oleh organisasi partai.

Penggunaan relawan dalam pemilu ikut mengubah pendekatan partai politik. Partai politik yang menggunakan struktur berbeda dengan cara kerja relawan yang berbasis sukarela dan dinamis. Perbedaan pendekatan organisasi partai dan relawan menyebabkan keduanya sulit bertemu dalam koordinasi politik. Perubahan yang dilakukan Golkar dengan membentuk relawan dari internal politik bentuk adaptasi partai terhadap perubahan politik yang memanfaatkan peran relawan.

Pada sisi Golkar, penggunaan relawan dari dalam partai politik juga memiliki hubungan dengan kampanye yang dilakukan Golkar di Pemilu 2019. Para Caleg Golkar yang akan maju di Pemilu 2019 mengampanyekan diri lewat gagasan Gojo: video, baliho, dan lainnya.

Dengan dibentuknya Gojo diperkirakan hanya mempengaruhi pola kampanye politik Partai Golkar yang selama ini hanya fokus dengan jaringan dan struktur partai. Pada Pemilu 2019 terjadi perubahan politik dengan Golkar menggunakan media digital dan relawan politik sebagai strategi pemilu. Caleg yang berasal dari Golkar mengampanyekan Jokowi dengan Golkar yaitu dengan memasang baliho Airlangga dan Jokowi yang dengan dukungan relawan Gojo.

Selain itu, terjadi perubahan pola kampanye yang dilakukan oleh Golkar di

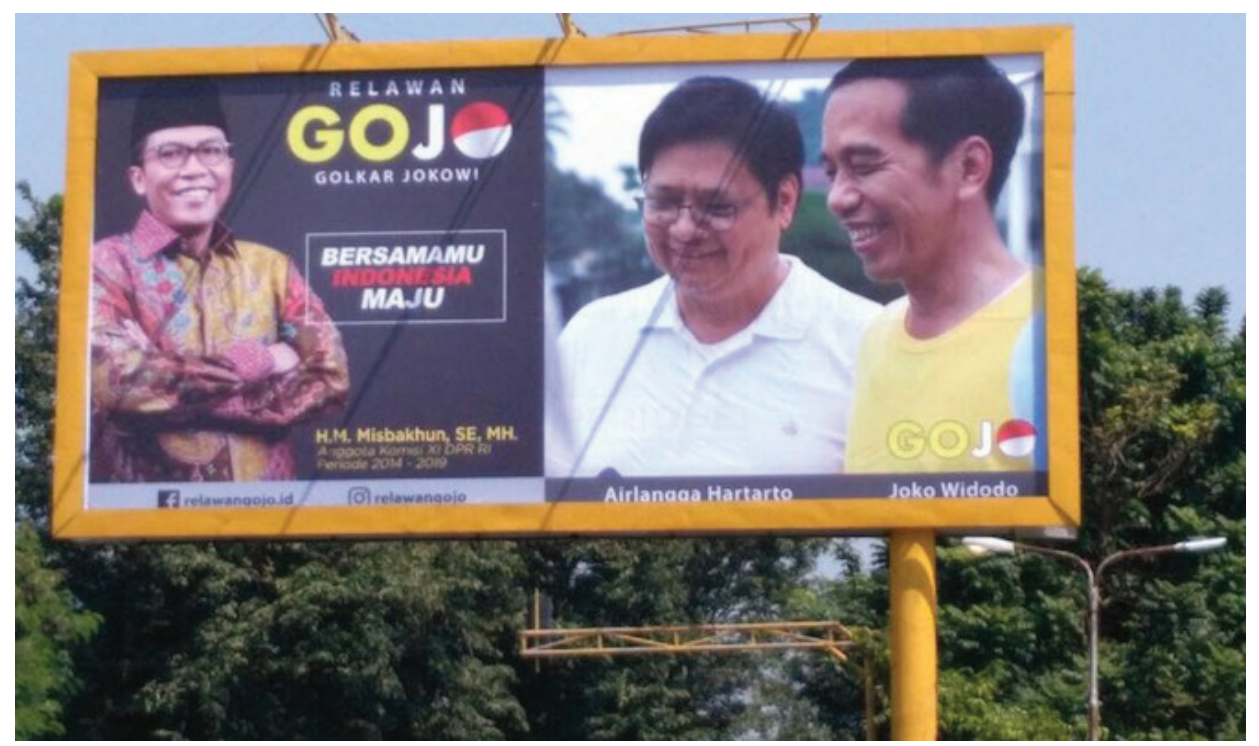

Gambar 1. Baliho Misbahkun, Calon Anggota DPR-RI di Pemilu 2019 Sumber: Jawa Pos 
Pemilu 2019. Partai Golkar mendapatkan dukungan pemanfaatan teknologi dengan menggunakan aplikasi Augmented Reality untuk membangun engagement dengan calon pemilih atau pun caleg partai Golkar di Pemilu 2019. ${ }^{2}$ Golkar adalah partai yang pertama kali memanfaatkan teknologi dan pengetahuan untuk meningkatkan kinerja caleg.

Relawan Gojo diasumsikan juga ikut membawa perubahan terhadap komposisi caleg Golkar di Pemilu 2019. Di Pemilu 2019, Golkar sepertinya sedang menyesuaikan komposisi caleg nasional partai dengan representasi generasi milenial. Dari 573 caleg DPR se-Indonesia yang maju sebagai calon DPR-RI, Golkar menyiapkan 133 caleg yang berasal dari kelompok milenial. ${ }^{3}$ Strategi Golkar mendorong caleg-caleg muda tersebut berdampak dengan terbukanya kesempatan tokoh muda maju sebagai caleg.

\section{Rumusan Masalah}

Dengan kecilnya keuntungan yang didapatkan koalisi pendukung calon presiden di Pemilu 2019 yang bukan berasal dari PDI-P dan Gerindra. Maka, Golkar yang mengusung Jokowi mencari strategi untuk mendapatkan dampak atas dukungan terhadap calon presiden. Salah satu hal yang dilakukan oleh Golkar adalah dengan mendukung Jokowi jauh sebelum Pemilu 2019. Dukungan tersebut diungkapkan di Musyawarah Nasional (Munaslub) Partai Golkar, pada masa pergantian kepemimpinan Setya Novanto ke Airlangga Hartarto.

Dukungan Golkar terhadap Jokowi pada periode kedua direalisasikan dengan

2 "Golkar akan Luncurkan Aplikasi Augmented Reality untuk Kampanyekan Jokowi,” 7 April 2019, diakses 17 Mei 2021, https://www.gatra.com/detail/ news/408116-Golkar-akan-Luncurkan-AplikasiAugmented-Reality-untuk-Kampanyekan-Jokowi.

3 "Golkar Beri Ruang yang Cukup Luas bagi Caleg Milenial." Diakses 5 April 2021. https://m. mediaindonesia.com/politik-dan-hukum/226944/ golkar-beri-ruang-yang-cukup-luas-bagi-caleg-milenial. pembentukan relawan politik. Dua relawan yang tersebut adalah Jaringan Karya Bersama Joko Widodo (Jangkar Bejo) dan GolkarJokowi (Gojo). Relawan ini bekerja untuk mengampanyekan Jokowi dengan membentuk jaringan ke daerah-daerah. Selain itu, relawan ini juga mendukung untuk penyelenggaran Pilkada serentak, Plemilu, dan Pilpres 2019. ${ }^{4}$

Apakah perubahan terhadap rekrutmen dan pola kampanye politik Golkar di Pemilu 2019 memiliki korelasi dengan keberadaan Relawan Gojo? Golkar yang didukung oleh infrastruktur organisasi sayap partai yang mapan dan modern, pada Pemilu 2019 menggunakan pendekatan berbeda. Fokus dari penelitian ini adalah tentang gangguan (disrupsi) yang terjadi di organisasi Golkar dengan dibentuknya relawan politik. Penggunaan relawan Gojo diasumsikan bentuk dari disrupsi di internal Golkar, dengan adanya perubahan pendekatan politik yang berbasiskan institusional ke pendekatan relawan. Haliniyang diperkirakan memberikan dampak terhadap perubahan rekrutmen dan pola kampanye Partai Golkar di Pemilu 2019.

\section{Tujuan Penulisan}

Tulisan ini bertujuan untuk melihat fenomena disrupsi politik yang terjadi di Partai Golkar. Dukungan yang diberikan Golkar kepada Jokowi di Pemilu serentak 2019 berkemungkinan menganggu organisasi Golkar. Apalagi dengan dibentuknya relawan politik akan mempengaruhi pola kerja organisasipartai. Tulisanakan memperlihatkan posisi Golkar melihat relawan politik sebagai gangguan terhadap organisasi, atau adaptasi Golkar sebagai partai yang sudah mapan berhadapan dengan perubahan politik.

4 "Demi Jokowi untuk Dua Periode, Golkar Siapkan Relawan Siap Perang,” diakses 18 Juli 2021, https:// www.jawapos.com/nasional/politik/19/02/2018/ demi-jokowi-untuk-dua-periode-golkar-siapkan-relawansiap-perang/. 


\section{Metode Penelitian}

Tulisan ini menggunakan metode kualitatif dengan menggunakan data primer dan data sekunder. Berdasarkan data awal dari data sekunder permasalahan penelitian ini, maka lokasi penelitian ini berlokasi di DPP Partai Golkar, DKI Jakarta, dan beberapa DPD Golkar lainnya yang fokus terhadap relawan Golkar-Jokowi. Pilihan terhadap DKI Jakarta sebagai lokasi utama karena berlatar belakang dengan gerakan ini dimulai oleh DPD DKI Jakarta. Periode pengamatan data penelitian ini dimulai sejak 23 September 2018-13 April 2019. Jadwal ini adalah masa kampanye calon anggota DPR, DPD, dan DPRD, serta pasangan calon Presiden dan Wakil Presiden di Pemilu 2019.

Pendekatan yang digunakan dalam penelitian ini adalah kualitatif. Penelitian kualitatif berfikir dari umum ke khusus (induktif). Penelitian kualitatif tidak dimulai dengan mengajukan hipotesis dan kemudian menguji kebenarannya (berfikir deduktif), melainkan bergerak dari bawah dengan mengumpulkan data sebanyak mungkin tentang sesuatu, dan dari data itu dicari pola pola, hukum, prinsip-prinsip, dan akhirnya menarik kesimpulan dari analisis yang telah dilakukan.

\section{Kerangka Pemikiran}

Disrupsi

Disrupsiawalnyaberkembang padakonteks bisnis, setelah itu masuk ke ranah hiburan, politik, investasi, budaya dan pemerintahan. Sarjana yang dikaitkan tentang kajian disrupsi adalah Clayton M. Christensen dan Francis Fukuyama. Keduanya mempunyai pandangan berbeda tentang Disrupsi. Christensen melihat disrupsi sebagai peluang, sedangkan Fukuyama sebagai kekacauan (gangguan). Tulisan ini akan menggunakan konsep disrupsi yang diperkenalkan Fukuyama.

\section{a. Konsep Disrupsi Fukuyama}

Dalam buku The Great Disruption: Human Nature and the Reconstitution of Social Order karya Francis Fukuyama, hadirnya masyarakat informasi gangguan terhadap tatanan sosial formal. Menurut Fukuyama, masyarakat yang dikondisikan oleh kekuatan informasi cenderung menghargai nilai-nilai yang dijunjung tinggi dalam demokrasi, yaitu kebebasan (freedom) dan kesetaraan (equality). Kebebasan memilih mencuat tinggi sebagai hak, sementara semua jenis hirarki (dalam agama, politik, pemerintahan, bisnis, dan lain-lain) digerogoti daya regulasi dan kecenderungan koersifnya. ${ }^{5}$

Birokrasi-birokrasi yang besar dan kaku dibuat melalui kebijakan dan peraturan akan ditinggalkan oleh perubahan. Hadirnya informasi, masyarakat berkeinginan mengakses sesuatu secara langsung tanpa harus berurusan dengan lembaga-lembaga formal. ${ }^{6}$ Kekuasaan tidak bergantung lagi kepada satu orang, saat persoalan-persoalan masyarakat semakin kompleks. Penguasa atau pemimpin lembaga tidak bisa menyelesaikan masalah hanya dengan mengandalkan dirinya sendiri. Dengan adanya pendelegasian otoritas kepada pakar atau ahli teknologi menyelesaikan masalah. Maka, kekuasaan seorang penguasa atau pemimpin lembaga telah terbagi kepada individu tertentu. ${ }^{7}$ Fukuyama mengakui keuntungan atau manfaat yang timbul dari perubahan-perubahan teknologi, sehingga masyarakat menjadi suatu "masyarakatinformasi" (information society). Kesejahteraan, demokrasi, kesadaran akan hak asasi dan kepedulian terhadap lingkungan hidup, merupakan contohnya

Dalam organisasi, kekuasaan yang terlihat dengan jelas adalah kekuatan formal. Namun

\footnotetext{
5 Francis Fukuyama, The Great Disruption: Hakikat Manusia dan Rekonstitusi Tatanan Sosial, (Yogyakarta: Qalam, 2014), 4.

6 Fukuyama, The Great Disruption, 4.

7 Fukuyama, The Great Disruption, 318-320.
} 
pada sisi lain, kekuatan informal berkembang dengan adanya jaringan yang tidak terikat dengan organisasi. Jaringan adalah agen yang dibentuk karena didukung oleh nilai-nilai dan norma berdasarkan basis kepercayaan. Sebaran pengaruhnya tidak bersifat formal dan hirarki, akan tetapi dengan otoritas informal berbagai organisasi. Para anggota dalam organisasi formal hanya membagi informasi kepada lembaganya sesuai dengan kontrak dan kesepakatan awal. ${ }^{8}$

Maka dari itu, disrupsi oleh informasi terhadap lembaga-lembaga formal, seperti: perusahaan, organisasi, dan negara, bukti kegagalan dari sentralisasi. Kegagalan tersebut disebabkan karena tidak memahami perkembangan dunia yang kompleks. Hierarki yang dijalankan oleh organisasi mengalami masalah ketika perubahan terjadi di bidangbidang tertentu, dengan adanya transformasi era industri ke informasi. ${ }^{9}$ Dalam masyarakat informasi pemerintah atau perusahaan tidak akan secara eksklusif mengatur dengan formal masyarakat yang berada dibawah otoritasnya. Akan tetapi, mereka harus melakukan desentralisasi atau memindahkan kekuasaan dengan swa-organisasi. Swa-organisasi adalah peraturan yang terinternalisasi dengan normanorma informal. ${ }^{10}$

Perubahan tren-tren sosial masyarakat terjadi dengan adanya peralihan era industri ke informasi. Industri yang menggunakan pendekatan struktural dan rasional rusak tatanannya akibat masuknya era informasi. Individualisme yang berkembang di era informasi menyebabkan tren sosial yang bertumbuh dan berinovasi merusak tatanan sosial yang sudah ada. Karena itu, budaya individualisme yang masuk ke ruang sosial akan merusak ikatan sosial yang ada di keluarga, kelompok, dan negara. ${ }^{11}$ Selain itu,

8 Fukuyama, The Great Disruption, 326-328.

9 Fukuyama, The Great Disruption, 318.

10 Fukuyama, The Great Disruption, 8-9.

11 Fukuyama, The Great Disruption, 4-7. informasi beredar di dalam struktur organisasi lebih mudah karena dengan adanya otoritas formal yang mendukung. Perpindahan informasi dari atas kebawah dalam organisasi terkendala oleh kepentingan pribadi agen organisasi yang akan memperluas informasi. Ketidaksesuaian insentif yang didapatkan oleh masing-masing individu menyebabkan terjadi pemisahan informasi untuk individu dan organisasi. ${ }^{12}$

\section{b. Pelembagaan Politik Huntington (1968)}

Konsep disrupsi Christensen kurang cocok menjelaskan tentang disrupsi yang terjadi di Partai Golkar. Maka dari itu, tulisan ini akan didukungoleh teori pelembagaan partai politik. Huntington mendefinisikan pelembagaan politik dimana organisasi memperoleh nilainilai baku dan stabil. Terdapat empat dimensi syarat tingginya pelembagaan partai politik yaitu adaptabilitas, kompleksitas, otonomi, dan koherensi. Namun, dalam penelitian ini peneliti hanya menggunakan dimensi Adaptabilitatas. Huntington menjelaskan bahwa pelembagaan politik yang baik, maka partai politik harus mampu beradaptasi dengan perubahan. Karena itu, semakin tinggi derajat pelembagaan partai politik maka semakin tinggi kemampuannya menyesuaikan diri. ${ }^{13}$

Terkait dengan kemampuan partai politik beradaptasi, Huntington mengajukan beberapa kriteria: Pertama, umur organisasi, yang diukur melalui(i) Perhitungan kronologis, semakin tua organisasi maka semakin besar potensi untuk survive, (ii) usia generasi: semakin tinggi suatu organisasi melakukan pergantian tokoh maka semakin baik pelembagaan politiknya dan lebih dari itu organisasi mampu melakukan alih kepemimpinan dengan damai, (iii), fungsi organisasi: kemampuan partai politik untuk

12 Fukuyama, The Great Disruption, 329-330.

13 Samuel. P. Huntington, Political Order in Changing Societes (New Haven and London, Yale University Press, 1968), 83-31. 
mengubah fungsi awal mereka, ketika fungsi awal tersebut tidak dibutuhkan lagi. ${ }^{14}$

\section{Pembahasan}

\section{Adaptasi Politik Golkar Pasca Reformasi}

Sejak jatuhnya pemerintahan Soeharto tahun 1998 banyak sarjana memperkirakan berdampak dengan bubarnya Golkar. Namun kenyataannya, Partai Golkar mampu survive melewati era transisi untuk tetap eksis di setiap pemilu. Golkar sukses melewati dua pilihan, bertahan dengan citra lama atau menggunakan pendekatan baru. Namun, Golkar memilih beradaptasi, seperti istilah yang diberikan Huntington untuk partai politik yang mampu beradaptasi yakni dengan mengubah fungsi awal partai ketika fungsi tersebut tidak digunakannya lagi. ${ }^{15}$

Golkar yang dicitrakan sebagai partainya Soeharto, pascareformasi 1998 pengaruhnya mulai dihilangkan di internal Golkar. Turunnya Soeharto sebagai presiden, ikut mempengaruhi konstelasi internal Golkar, dengan adanya Munas Luar Biasa (Munaslub). Munaslub ini mempertemukan kelompok militer yang mengusung Edi Sudrajat dengan kelompok sipil yang mencalonkan Akbar Tandjung. Sementara itu, Soeharto tidak melepaskan jabatan sebagai Dewan Pembina Partai Golkar pasca-mundur sebagai presiden. Hal ini tetap tidak memberikan kemenangan kubu militer di pemilihan ketua umum. Kalahnya calon yang direkomendasikan oleh militer, bukti mulai lemahnya figur Soeharto di internal Golkar. ${ }^{16}$

Pada sisi lain, menangnya Akbar Tandjung sebagai Ketua Umum Golkar merupakan disrupsi terhadap pengaruh Soeharto di Internal Golkar. Disrupsi merupakan gangguan atau kekacauan terhadap kelembagaan

14 Huntington, Political Order in Changing Societes, 83-31. 15 Huntington, Political Order in Changing Societes, 83-31.

16 Akbar Tandjung, The Golkar Way: Survival Partai Golkar di Tengah Turbulensi Politik Era Trandisi, (Jakarta: PT. Gramedia Pusataka Utama, 2007) 10-11. yang disebabkan oleh informasi. Goyahnya pemerintahan Soeharto menjelang tahun 1998 salah satunya disebabkan oleh terbukannya informasi yang didapatkan oleh masyarakat. Informasi ini berdampak dengan perubahan organisasi Golkar yang ikut dengan harapan dan suara publik dengan meninggalkan citra sebagai partainya Orde Baru.

Disrupsi yang terjadi di internal Golkar salah satunya dilatarbelakangi dengan berkembangnya industri pers di Indonesia. Pers yang dulu milik orang-orang pers pindah kepemilikan kepada orang-orang non-pers. Pengusaha-pengusaha ikut terjun ke dunia pers dengan memanfaatkan perkembangan kelas menengah yang butuh informasi. ${ }^{17}$ Kepemilikan terhadap pers oleh pebisnis menyebabkan Soeharto sulit melakukan tindakan refresif terhadap media seperti sebelumnya. Kontrol yang dilakukan pemerintah terhadap media tidak sampai dengan memaksa pers mendukung narasi pemerintah. ${ }^{18}$

Selain itu, dengan adanya peralihan kepemilikan dunia pers maka masyarakat memiliki alternatif untuk mendapatkan informasi. Apalagi pemerintah sebelumnya juga mendirikan lisensi RADNET (PT. Rahajasa Media Internet) tahun 1996 sebagai ISP (Internet Service Provider) komersial pertama yang memberikan informasi ke seluruh Indonesia. ${ }^{19} \mathrm{Hal}$ ini memberikan dampak yang besar ke dunia pemberitan dan peredaran informasi ke masyarakat.

Makanya, mudahnya akses yang didapatkan oleh masyarakat berdampak terhadap perbincangan politik Orde Baru yang sebelumnya tertutup menjadi terbuka.

17 Yasuo Hanazaki, Pers Terjebak, (Jakarta: Institute Studi Arus Informasi), 1998: 7-8.

18 Rully Chairul Azwar, Politik Komunikasi Partai Golkar di Tiga Era: Dari Hegemonik ke Partai Berorientasi Pasar, (Jakarta: Gramedia Widiasarana Indonesia), 2009: 13 14.

19 Idham Holik. "Teknologi Baru Media Dan Demokratisasi Di Indonesia". Jurnal Makna, Volume 1. Nomor 2. (September 2010 - Februari 2011). 
Dalam konsep Fukuyama (2014) bahwa dalam masyarakat informasi pemerintah atau perusahan (organisasi) tidak ekslusif mengatur dengan formal orang yang berada dibawah otoritasnya. Pemimpin harus melakukan desentralisasi atau memindahkan kekuasaan dengan swa-organisasi.

Kekuasaan Orde Baru yang formal dan sentralistik mendapatkan "gangguan" dari internal Golkar yang menunggu kejatuhan Soeharto. Lemahnya kekuasaan Soeharto, elite yang terbentuk lewat jaringan informal di internal Golkar muncul sebagai calon pemimpin baru organisasi. Karena itu, kemenangan pemimpin sipil yang diwakili oleh Akbar Tandjung merupakan hasil dari kelompok-kelompok informal yang sedang menunggu lemahnya Soeharto.

Dibawah kepimpinan Akbar Tandjung disrupsi terhadap pengaruh Soeharto diperkuat dengan dihapuskannya jabatan Ketua Dewan Pembina Partai Golkar dalam struktur kepengurusan. ${ }^{20}$ Hilangnya peran Soeharto di Golkar berdampak dengan berkurangnya pengaruh militer. Kekalahan militer dalam perebutan kursi ketua umum menyebabkan beberapa kelompok militer keluar dari Golkar. Selain itu, perubahan tersebut menyebabkan organisasi sayap Golkar sibuk dengan konflik internal. Hal ini yang menyebabkan mereka keluar dari Golkar.

Dibalik hilangnya pengaruh Soeharto, Golkar menjaga jarak dengan keluarga dan orang dekatnya. Golkar kepemimpinan Akbar Tandjung memperkenalkan Golkar yang berbeda kepada masyarakat, sehingga Golkar sebagai partai yang mendapatkan hujatan masyarakat pada Pemilu 1999 berubah menjadi partai yang diterima kembali kehadirannya. Azwar (2009) menjelaskan kritik terhadap Golkar dijawab dengan memperkenalkan Golkar Baru. Hasilnya, Golkar memenangkan Pemilu 2004 dengan mampu bersaing dengan

20 Tandjung, The Golkar Way, 9. partai yang hidup era Orde Baru dan partai yang berdiri pascareformasi. ${ }^{21}$

Keberhasilan Golkar beradaptasi pascareformasi diperkirakan karena memiliki institusional yang baik dan mapan. Golkar sukses mengelola sumber daya yang ada di internal dan menangkap perubahan di eksternal. Huntington menyebutkan partai yang mampu beradaptasi adalah yang paling panjang usianya. Eksisnya Golkar pascareformasi merupakan jawaban terhadap asumsi banyak sarjana tentang usia Golkar yang berakhir pasca-turunnya Soeharto.

Pada pemilu pascareformasi Golkar beradaptasi dengan perubahan politik yang terjadi, sehingga ini yang mendorong Golkar tetap eksis di pemerintahan. Misalnya, Pilpres 2004 Golkar mengadakan konvensi partai dengan memberikan kesempatan kepada siapa saja maju sebagai calon presiden. ${ }^{22}$ Konvensi ini dimenangkan oleh Wiranto, maka di Pilpres 2004 Golkar mengusung WirantoSalahudin Wahid sebagai calon presiden dan wakil presiden. Akan tetapi, hasil Pilpres 2004 dimenangkan pasangan Susilo Bambang Yudhoyono (SBY) - Jusuf Kalla (JK).

Kemenangan JK sebagai wakil presiden berpengaruh terhadap konstelasi internal partai. Pergantian kepemimpinan partai selanjutnya, JK menang di pemilihan ketua umum. Pergantian kepemimpinan ini menyebabkan Golkar bergabung sebagai partai pendukung pemerintah. Hal yang sama juga terjadi pada Pilpres 2009, Golkar mendukung JK-Wiranto sedangkan SBY berpasangan dengan Boediono. Akan tetapi, pasangan JKWiranto kalah di Pilpres 2009. Hasil pilpres ini berdampak dengan perubahan politik di internal Golkar, dengan kepemimpinan Golkar selanjutnya dimenangkan oleh Aburizal Bakrie. Golkar dibawah kepemimpinan Aburizal Bakrie pun mengambil langkah

21 Azwar, Politik Komunikasi Partai Golkar di Tiga Era. 22 Tandjung, The Golkar Way, 92. 
yang sama yakni bergabung sebagai partai pendukung pemerintah.

Pada Pilpres 2014 Golkar tetap eksis di pemerintahan meskipun calon yang didukungnya kalah. Golkar mendukung pasangan Prabowo-Hatta sebagai calon presiden dan wakil presiden. Akan tetapi, pasangan ini dikalahkan oleh Jokowi-JK (Mantan Ketua Umum Golkar). Menangnya Jokowi-JK di Pilpres 2014 kembali ikut merubah konstelasi politik di internal Golkar. Dualisme kepemimpinan di internal Golkar antara kubu Aburizal Bakrie dengan Agung Laksono dimanfaatkan oleh Golkar untuk meninggalkan koalisi oposisi untuk bergabung ke pemerintahan Jokowi.

Masuknya Golkar pada periode pertama pemerintahan Jokowi, pemilu serentak 2019 Golkar mendukung Jokowi sebagai presiden. Dengan Pemilu 2019 pileg dan pilpres dilaksanakan bersamaan, sistem pemilu ini berpotensi menguntungkan partai yang kadernya maju sebagai calon presiden. Oleh karena itu, Jokowi tidak hanya sukses mengganggu tatanan sosial lembaga PDI-P, dengan besarnya kesempatannya untuk mendapatkan karir politik sejak Pilkada DKI Jakarta sampai dengan Pemilu 2019. Golkar yang mendukung Jokowi di Pemilu 2019 beradaptasi dengan pendekatan yang digunakan oleh Jokowi dengan ikut membentuk relawan dari dalam partai politik.

\section{Jokowi dan Disrupsi Politik}

Sosok Jokowi dalam politik Indonesia merupakan gangguan (disrupsi) terhadap tatanan partai politik. Dengan memulainya karir politik sebagai Walikota Surakarta yang jauh dari radar partai politik. Jokowi masuk ke ruang politik nasional dengan maju sebagai Gubernur DKI Jakarta tahun 2012. Dukungan Jokowi maju sebagai calon gubernur DKI Jakarta, pada awalnya tidak datang dari partai politik, akan tetapi dari relawan politik. Kelompok ini lah yang mendorong partai politik, Gerindra atau PDI-P punya pertimbangan untuk mengusung Jokowi di Pilkada. Relawan politik memanfaatkan media sosial untuk mendorong partisipasi politik masyarakat, sehingga citra Jokowi dengan mudah diperbincangkan. ${ }^{23}$

Pola yang digunakan relawan politik adalah dengan berinteraksi di platform media sosial, setelah itu dilanjutkan dengan pertemuan, pawai, dan rapat akbar. Tiga model penggunaan media sosial dalam partisipasi politik oleh relawan Jokowi-Ahok; (1) mengekspresikan preferensi politiknya; (2) mengampanyekan (mempromosikan) kandidat tertentu; (3) menggalang dukungan publik (mengajak pemilih). Media sosial tidak hanya sebagai wadah penyampaian dan penyebaran visi dan misi kandidat, tetapi juga wadah ekspresi relawan.

Kesuksesan Jokowi menang di Pilkada DKI Jakarta tahun 2012, berlanjut dengan majunya Jokowi di Pilpres 2014. Jokowi memanfaatkan jejaring relawan Pilkada DKI Jakarta tahun 2012 yang sudah teruji untuk maju di Pilpres tahun 2014. ${ }^{24}$ Kajian yang dilakukan oleh Jati (2016) menyatakan gerakan relawan untuk Jokowi di Pemilu 2014 sukses dilatar belakangi oleh; 1) Jokowi memiliki modal sosial dengan relawan politik yang aktif pada Pilkada DKI Jakarta 2012; dan (2) relawan politik yang aktif sebagai pendukung Jokowi adalah kelas menengah yang selama ini tidak berpihak dengan politik.

Pada konteks yang sama, Arianto (2014) juga menjelaskan bahwa kontestasi presidensial 2014 diwujudkan dengan kehadiran relawan politik. ${ }^{25}$ Kebangkitan

23 Fayakhun Andriadi, Demokrasi Di Tangan Netizen: Tantangan dan Prospek Demokrasi Digital, (Jakarta: Rmbook, 2016).

24 Wasisto Raharjo Jati, "Aktivisme Kelas Menengah Berbasis Media Sosial: Munculnya Relawan dalam Pemilu 2014," Jurnal Ilmu Sosial dan Ilmu Politik Volume 20, No. 2 (November 2016): 147-116.

25 Bambang Arianto, "Fenomena Relawan Politik dalam Kontestasi Presidensial 2014,” Jurnal Ilmu Sosial dan 
gerakan sosial melahirkan tradisi voluntarisme, yang mentransformasi nilai-nilai politis bernuansa patrimonial dan oligarkis menjadi partisipatoris. $^{26}$ Selan itu, relawan yang bergerak secara langsung dan dunia maya mendorong partisipasi publik. Kehadiran relawan memberikan dampak positif terhadap pembangunan model demokrasi ekstra parlementer. Namun, pada sisi lain yang perlu diperhatikan yakni kehadiran relawan pada satu sisi ikut mengurangi dominasi partai politik.

Dukungan relawan kepada Jokowi menggunakan kreativitas dan seni, seperti kampanye kreatif lewat video, musik, aplikasi game, dan desain visual. ${ }^{27}$ Transformasi politik dari model kampanye konvensional menuju kampanye modern. Kemunculan kampanye kreatif berkembang sebagai saluran komunikasi politik yang efektif dalam membangun budaya partisipatoris. Kampanye kreatif yang dilakukan oleh relawan berdampak positif dalam mendorong perubahan perilaku politik kewargaan yang kemudian melahirkan politik kegembiraan.

Kesuksesan Jokowi di Pilkada DKI Jakarta 2012 dan Pilpres 2014 dilatarbelakangi oleh gangguan kelompok relawan terhadap partai politik. Populeritas yang dimiliki Jokowi mengharuskan partai politik mendukungnya di pemilihan, agar efek elektoral Jokowi berdampak kepada suara partai politik di parlemen. Pada Pemilu 2019, pilihan partai koalisi pendukung Jokowi, selain PDI-P yang duntungkan dengan mendukung JokowiGolkar sebagai bagian dari partai pendukung juga mengklaim Jokowi sebagai bagian dari Golkar.

Ilmu Politik Volume 18, No. 2 (November 2014): 130146.

26 Arianto, "Fenomena Relawan Politik." 130-146.

27 Bambang Arianto, "Kampanye Kreatif dalam Kontestasi Presidensial 2014." Jurnal Ilmu Sosial dan Ilmu Politik Volume 19, No. 1 (Juli 2015): 16-39.

\section{Gojo dan Disrupsi Politik Golkar}

Golkar mendukung Jokowi jauh sebelum Pemilu 2019. Ini merupakan upaya Golkar untuk mendapatkan keuntungan dari pemilu serentak. Sejak awal Golkar tidak memiliki kader unggulan maju sebagai calon presiden, seperti PDI-P mempunyai Jokowi dan Gerindra memiliki Prabowo. PDI-P mendapatkan keuntungan di pemilihan legislatif karena mendukung Jokowi, begitu pun juga dengan Gerindra yang mempunyai kader yang maju sebagai calon presiden (Prabowo). Akan tetapi, keuntungan tersebut tidak didapatkan oleh koalisi partai pendukung masing-masing calon presiden.

Partai koalisi pendukung Jokowi dan Prabowo cendrung mengalami split ticket voting atas pilihannya terhadap calon presiden. Split Ticket Voting adalah terjadinya perbedaan pilihan loyalis dengan pengurus partai untuk dukungan calon presiden, sehingga menyebabkan pemilih membagi pilihan politik untuk partai dan presiden. Karena itu, koalisi partai dirugikan mendukung Jokowi jika basis pemilihnya mendukung Prabowo atau pun sebaliknya.

Pada Pemilu 2019 Partai Golkar, hawatir dengan suaranya turun drastis dibandingkan pemilu sebelumnya. Perkiraan turunnya suara Golkar pada Pemilu 2019 didukung oleh dua hal. Pertama, Golkar disibukan dengan dualisme kepemimpinan (kubu Agung Laksono dan Aburizal Bakrie). Kedua, ketua umum Partai Golkar Setya Novanto dan sekretaris Idrus Marham, ditangkap oleh KPK. Dua hal tersebut diperkirakan Golkar sulit selamat melalui Pemilu 2019.

Tertangkapnya Setya Novanto dalam kasus korupsi, maka Partai Golkar melakukan pergantian kepemimpinan ke Airlangga Hartarto yang dipilih lewat Munaslub tahun 2017. Terpilihnya Airlangga meninggalkan dua pekerjaan penting untuk Golkar. Pertama untuk mengembalikan citra Golkar di mata 
publik dan kedua, strategi yang dilakukan Golkar untuk menghadapi Pemilu serentak 2019.

Dalam menyelesaikan hal tersebut, Golkar dibawah kepemimpinan Airlangga melakukan strategi kreatif untuk meningkatkan citra partai di Pemilu 2019, yakni dengan memanfaatkan citra Jokowi untuk kepentingan Golkar. Hal yang dilakukan oleh Golkar adalah dengan membentuk relawan politik, salah satunya Golkar-Jokowi. Gojo merupakan relawan yang menggabungkan entitas Golkar dengan Jokowi (Gojo). Tingginya elektabilitas petahana (Jokowi) hanya memberikan keuntungan terhadap PDI-P, maka dengan mendirikan Gojo-Golkar ingin melakukan co-branding terhadap Jokowi. ${ }^{28}$

Gojo adalah media Golkar untuk berkomunikasi dengan pemilih yang belum menentukan pilihan. Jokowi sebagai calon presiden mempunyai pemilih tersendiri. Pemilih menyukai Jokowi karena pendekatan politiknya yang berbeda dan posisi Jokowi sebagai petahana. Karena itu, Golkar memanfaatkan pemilu serentak dengan mendorong pemilih Jokowi yang tidak meyukai PDI-P untuk memilih Golkar.

Dari dua relawan yang dibentuk oleh Golkar, relawan Gojo lebih masif dan solid dalam strategi kampanye pemenangan Pemilu 2019. Burhanudin Muhtadi, Direktur Eksekutif Indikator Politik Indonesia menyebutkan relawan Gojo memiliki peran penting terhadap kampanye pemenangan Jokowi-Ma'ruf. Hal ini dilatarbelakangi dengan Gojo melakukan inovasi yakni dengan pemanfaatan media sosial dalam kampanye politik. Strategi yang dilakukan oleh Gojo, upaya Golkar untuk mendapatkan efek ekor jas dari citra Jokowi. ${ }^{29}$

28 Gatra. "Strategi Relawan Gojo yang Aktif Kampanyekan Jokowi di Medsos," diakses 27 Juni 2020, https:// www.gatra.com/detail/news/372424-Strategi-RelawanGojo-yang-Aktif-Kampanyekan-Jokowi-di-Medsos.

29 Muhammad Raditoyo Priasmoro, "Indikator Politik: Golkar Partai Paling Solid Dukung Jokowi-Ma'ruf,"
Relawan Gojo didirikan atas inisiatif Rizal Mallarangeng yang saat itu menjabat sebagai Plt Ketua DPD Golkar DKI Jakarta. Rizal merumuskan relawan Gojo di Kafe Paradigma, yang letaknya bagian dari kantor Golkar DKI Jakarta, Cikini, Jakarta Pusat. Rizal mempresentasikan kepada Ace Hasan Syadzily tentang rencana membentuk relawan Golkar-Jokowi untuk mendukung Jokowi di Pemilu 2019.30 Pasca-dibentuk Rizal Mallarangeng, ia menjabat sebagai Koordinator Nasional Relawan Gojo, yang bertugas mengkonsolidasikan jaringan relawan ke daerah-daerah seluruh Indonesia.

Relawan Gojo terdiri dari kelompok organisasi sayap partai, kader Milenial Golkar, dan Kelas Menengah (milenial) pendukung Jokowi. ${ }^{31}$ Gojo bertugas untuk memenangkan Jokowi pada Pilpres 2019, serta memberikan dampak dukungan tersebut terhadap suara Golkar di pemilihan legislatif. Karena itu, nama relawan Golkar-Jokowi (Gojo) secara langsung juga ikut mengampanyekan Jokowi dan Golkar.

Pola koordinasi relawan Gojo melepaskan diri dari jejaring lembaga partai secara organisasi, namun secara swaorganisasi Gojo menunjuk ketua DPD di daerah sebagai ketua Gojo, dengan pola koordinasi berbasis relawan. Relawan Gojo bergerak tetap memanfaatkan jaringan yang dimiliki oleh Golkar dengan pemanfaatan struktur partai. Namun, pendekatannya tidak mengunakan jalur koordinasi partai. Peran Rizal Mallarangeng, sebagai koordinator nasional, berkoordinasi dengan petinggi di daerah untuk membentuk relawan politik, dan ikut dengan kampanye Jokowi. ${ }^{32}$

diakses 27 Agustus 2021, https://www.liputan6.com/ news/read/3858373/indikator-politik-golkar-partaipaling-solid-dukung-jokowi-maruf.

30 Majalah Tempo, "Partai Pembonceng Jokowi," 18 Maret 2018.

31 Media Indonesia. "Golkar Beri Ruang yang Cukup Luas bagi Caleg Milenial."

32 Wawancara dengan Rizal Mallarangeng, Ketua Koordinator Relawan Golkar-Jokowi, 14 Juli 2021, di 
Relawan politik seperti yang dibentuk Golkar tidak mengganggu (disrupsi) lembaga partai, atau menggantikan peran dari partai politik. Gojo memperluas peran dari Golkar untuk menarik pemilih yang tidak bisa diakses oleh jaringan partai. Kemampuan sumber daya manusia dan pengalaman Golkar beradaptasi dengan perubahan politik sejak reformasi dengan sukses meninggalkan citra Soeharto dan eksis sebagai partai yang diterima oleh masyarakat. Perubahan politik yang disebabkan oleh munculnya relawan politik, yang sebelumnya berlawanan dengan partai. Golkar menyatukan gerakan relawan dengan lembaga partai.

Eksperimen Golkar untuk memanfaatkan efek Jokowi untuk suara partai pada pemilu 2019 tidak lah keputusan partai. Menurut Rizal Mallarangeng, Gojo didirikan agar Golkar dengan mudah memanfaatkan jaringan yang belum disentuh oleh partai, sehingga agar gerakannya lebih cepat dari partai Gojo tidak memerlukan keputusan langsung oleh Partai Golkar. Namun, sejak awal didirikan Gojo selalu bergerak memperkenalkan caleg-caleg yang berasal dari Golkar. ${ }^{33}$

Perkenalan caleg-caleg Golkar lewat Gojo sebelum masuknya jadwal kampanye, bonus bagi Golkar karena dengan menggunakan nama relawan, para caleg lebih awal berkampanye kepada konstituen. Meskipun belum mencantumkan nama caleg dari partai Golkar, para caleg mendapatkan kesempatan untuk memulai kampanye tanpa melanggar peraturan pemilu. Dengan memisahkan Gojo dengan Golkar secara operasional, lebih memudahkan Golkar lewat Gojo berkampanye di media sosial sebelum jadwal kampanye. ${ }^{34}$

Dibentuknya Gojo oleh Golkar, partai ini tidak khawatir dengan perubahan politik yang terjadi di internal Golkar. Partai yang pada Pemilu 2014 mendukung Prabowo, pada

\footnotetext{
Aplikasi Zoom (virtual).

33 Wawancara dengan Rizal Mallarangeng.

34 Wawancara dengan Rizal Mallarangeng.
}

pemilu 2019 memilih mendukung Jokowi. Perbedaan pilihan politik partai bagi kader dan konstituen Golkar biasa karena Golkar bukan partai yang berbasiskan ideologis tertentu. Karena sejak awal didirikan, Golkar adalah golongan fungsional yang berkarya yang tidak ingin terlibat dengan konflik lintas ideologi. Ini lah latar belakang yang menyebabkan Golkar lebih mudah menerima perubahan di internal, termasuk dengan dibentuknya relawan politik yang dinamakan dengan Golkar-Jokowi.

Konsep ini menyesuaikan dengan gagasan yang disampaikan oleh Huntington tentang adaptabilitas. Semakin tinggi pelembagaan partai politik, maka dengan mudah pula partai beradaptasi dengan perubahan. Dengan mendirikan relawan politik, Partai Golkar ikut dengan perubahan yang diharapkan oleh publik, sehingga paket kebijakan dan struktur realitisnya sesuai dengan tuntutan pasar. Jadi, Gojo adalah cara Golkar sebagai institusi partai beradaptasi dengan perubahan, dengan mengikuti pasar politik yang sedang berkembang yakni pemanfaatan relawan dalam pemenangan pemilu. Golkar melakukan disrupsi di internal partai dengan menganggu tantanan organisasi partai yang bergerak sistematis.

Relawan politik yang dibentuk oleh Golkar berbeda dari relawan Jokowi-Ahok di Pilkada DKI Jakarta tahun 2012 atau dengan Teman Ahok di Pilkada DKI Jakarta 2017. Relawan politik yang terbentuk untuk mendukung Jokowi atau Ahok terpisah dengan gerakan partai politik. Namun, Partai Golkar menyatukan relawan dengan lembaga partai yakni dengan membentuk GolkarJokowi. Tujuan dari dibentuknya relawan Golkar-Jokowi adalah upaya Golkar ingin mendapatkan pemilih Jokowi di Pemilu 2019.35

35 Wawancara dengan Rizal Mallarangeng. 
Upaya Golkar untuk mendapatkan pemilih Jokowi di Pemilu 2019 tidak terlalu berdampak dengan suara partai. Dukungan yang diberikan oleh Golkar untuk Jokowi dengan dibentuknya relawan politik, tidak terlalu berdampak dengan suara Golkar di Pemilu 2019. Efek Ekor Jas Jokowi lebih didapatkan oleh PDI-P. Namun, Golkar sebelum Pemilu 2019 tidak punya pilihan selain memanfaatkan Efek Ekor Jas Jokowi, berharap citra Jokowi memberikan dampak terhadap suara Golkar. ${ }^{36}$

Pada sisi lain, secara kelembagaan Golkar memberikan ruang terhadap kader-kader muda maju sebagai calon legislatif. Pemilu 2019 Partai Golkar menyesuaikan representasi calon legislatif nasionalnya dengan generasi milenial. Dari 573 caleg DPR se-Indonesia Golkar menyiapkan 133 caleg yang berasal dari kelompok milenial. ${ }^{37}$ Strategi Golkar mendorong caleg-caleg muda untuk maju di Pileg menunjukkan perubahan dalam rekrutmen caleg Golkar tahun 2019.

Selain rekrutmen caleg yang representatif milenial, Golkar merupakan partai pertama di Indonesia yang menggunakan aplikasi Augmented Reality. Aplikasi ini digunakan untuk membangun engagement dengan calon pemilih partai atau pun caleg partai Golkar di Pemilu 2019. ${ }^{38}$ Karena itu, pada Pemilu 2019 Golkar memanfaatkan teknologi dan pengetahuan untuk meningkatkan kinerja calegnya dengan strategi yang kreatif dan inovatif.

Disrupsi yang terjadi di internal Golkar di Pemilu 2019 dengan lahirnya relawan politik, perubahan rekrutmen politik, dan

36 Wawancara dengan Ahmad Doli Kurnia, Wakil Ketua Umum DPP Golkar, 18 Juli 2021, di Aplikasi Zoom (virtual).

37 Media Indonesia. "Golkar Beri Ruang yang Cukup Luas bagi Caleg Milenial."

38 Gatra.com. "Golkar akan Luncurkan Aplikasi Augmented Reality untuk Kampanyekan Jokowi," diakses 17 Mei 2021, https://www.gatra.com/detail/ news/408116-Golkar-akan-Luncurkan-AplikasiAugmented-Reality-untuk-Kampanyekan-Jokowi. kampanye partai tidak berdampak signifikan untuk suara Golkar. Pemilu 2014 Golkar memperoleh 14,74 persen suara, sedangkan di Pemilu 2019 turun menjadi 12,31 persen. Akan tetapi, turunnya suara Golkar disebabkan oleh beberapa faktor. Pertama, Efek Ekor Jas dukungan Golkar untuk Jokowi tidak berdampak signifikan terhadap suara Golkar. Kedua, Golkar menjelang Pemilu 2019 dihadapkan dengan kasus korupsi Ketua Umum dan Sekretaris Jenderal, hal ini berdampak terhadap persepsi publik terhadap Golkar.

Catatan penting penelitian ini bukan lah Golkar sukses atau tidak mendapatkan Efek Ekor Jas Jokowi, akan tetapi disrupsi yang dilakukan terhadap lembaganya dengan membentuk relawan. Perkiraan Golkar sebelum Pemilu 2019 Golkar menginginkan bahwa dampak efek ekor jas Jokowi bukan hanya untuk PDI-P, sebagai koalisi pendukung Jokowi Golkar juga ingin mendapatkan efek dari calon presiden.

Upaya Golkar membentuk relawan Golkar-Jokowi untuk Pileg dan pilpres, secara kelembagaan, Golkar telah melakukan dua langkah disrupsi, pertama Jokowi memang sulit dimiliki secara formal karena berlatar belakang kader PDI-P. Akan tetapi, jaringan informal yang dibentuk oleh Golkar, kelembagaan partai memanfaatkan gerakan relawan untuk mendapatkan efek dari Jokowi. ${ }^{39}$

Cara kerja relawan yang berbeda dengan tim sukses, relawan dengan mudah bergerak tanpa harus diperhatikan lawan politik. Jaringan informal yang digerakan oleh Golkar, yang dikoordinasikan oleh Rizal Mallarangeng, secara formal Golkar tetap bekerja dengan organisasi partai yang ada, seperti organisasi sayap partai. Pengakuan Golkar secara formal tentang inisiatif membentuk relawan, tidak menghilangkan fungsi partai yang sudah terkoordinasi dengan baik.

39 Wawancara dengan Rizal Mallarangeng. 
Pendekatan yang lentur, pendirian relawan dalam partai politik, hal yang ingin dimanfaatkan Golkar. Penamaan Gojo juga disesuaikan dengan, salah satu aplikasi Ojek Online yaitu Gojek. Dengan awalan yang sama dengan Golkar, maka dimanfaatkan untuk co-branding Gojo agar lebih mudah viral dan diperbincangkan. ${ }^{40}$ Makanya, jika dilihat di koran dan media online, Gojo relawan yang paling massif mengampanyekan Jokowi di Pemilu 2019.

Selain itu, Inisiatif yang dilakukan oleh Gojo, kesempatan bagi Golkar untuk melakukan kampanye lebih awal dibandingkan partai lain. Dengan mengatasnamakan relawan, aturan pemilu yang ketat terhadap partai politik, dimanfaatkan celah tersebut oleh Golkar dengan kampanye lewat relawan Gojo. ${ }^{41}$ Keuntungan ini lah yang dimanfaatkan Gojo untuk melakukan konsolidasi ke daerahdaerah, dengan menggunakan instrumen partai di daerah untuk kampanye.

Rizal Mallarangeng mengkonsolidasikan relawan pengurus partai yang berada di daerah untuk memakai baju Gojo ketika Jokowi melakukan kunjungan. Peluang ini yang dimanfaatkan Golkar lewat relawan untuk mendapatkan efek dari Jokowi. Pola kerja partai yang memanfaatkan jaringan relawan, tidak mengharuskan lewat jalur koordinasi partai yang hierarki, akan tetapi lebih menyesuaikan diri dengan kondisi lapangan. Kelebihan ini lah yang dimanfaatkan Golkar lewat jaringan informal untuk memperluas basis pemilih partai. ${ }^{42}$

Rekrutmen partai tidak terpengaruh dengan kehadiran relawan politik dengan adanya perubahan strategi politik. Akan tetapi, munculnya relawan partai juga ikut dengan pola pemilih baru yang tergolong milenial. Maka dari itu, Golkar di Pemilu 2019 mendorong kader-kader Golkar milenial untuk maju di DPR-RI. Perubahan rekrutmen

40 Wawancara dengan Rizal Mallarangeng.

41 Wawancara dengan Rizal Mallarangeng.

42 Wawancara dengan Rizal Mallarangeng.
Golkar yang maju di DPR-RI, tidak sematamata momentum politik di Pemilu 2019, namun juga regenerasi anggota DPR-RI yang sudah beberapa periode. ${ }^{43}$

Klaim Golkar mendorong kader-kader milenial di Pemilu 2019 tidak terlepas dari kader yang berasal dari lingkungan Golkar. Partai Golkar belum melakukan kaderisasi milenial dengan memberi ruang lebih besar kepada milenial yang bukan berlatar belakang keluarga. Misalnya, kelompok baru yang keluarganya pertama kali masuk Golkar, akan tetapi memanfaatkan jaringan kepala daerah, legislator senior, dan petinggi Golkar untuk mendorong anak-anaknya maju lewat pemilihan legislatif. ${ }^{44}$

Dalam proses kampanye politik relawan politik (gojo) berperan membantu kampanye partai Golkar. Golkar melakukan perubahan politik dengan memilih pendekatan digital sebagai salah satu strategi politik, misalnya, masifnya kampanye lewat media sosial. Kampanye Golkar lewat media sosial mendukung caleg Golkar memperkenalkan diri lebih awal sebelum jadwal kampanye. Selain itu, dengan memperkenalkan Jokowi di kampanye Golkar, sisi milenial yang mayoritas ada di kelompok pendukung Jokowi membantu Golkar di media sosial.

Media sosial mendukung kekuatan sumber daya manusia kader Golkar yang selama ini membangun jaringan sampai ke level terendah. Dukungan media sosial menjadikan Golkar partai yang berbeda, tidak lagi identik dengan partai orang tua. Pendekatan lama yang dimiliki oleh Golkar dengan sumber daya manusia partai yang baik, modal dasar Golkar bertarung di Pemilu, yang melatarbelakangi keunggulan Golkar dibandingkan partai lain.

43 Wawancara dengan Ahmad Doli Kurnia.

44 Wawancara dengan Ujang Komarudin, Pengamat Politik, 13 Juli 2021, di Aplikasi Zoom (virtual). 


\section{Kesimpulan}

Dari uraian diatas dapat disimpulkan sebagai berikut: Pertama, gangguan (disrupsi) yang terjadi di Partai Golkar lewat perubahan politik yang terjadi di Pemilu 2019. Memiliki latar belakang kuat dengan adaptasi politik Golkar pascareformasi, Golkar survive dengan meninggalkan citra sebagai Partai Soeharto. Selain itu, perubahan sikap politik Golkar dari pemilu ke pemilu tidak lah persoalan bagi kader Golkar untuk menyesuaikan diri dengan perubahan.

Kedua, Golkar-Jokowi (Gojo) strategi Golkar beradaptasi dengan perubahan politik di Pemilu 2019 yang dilaksanakan secara serentak. Golkar yang tidak mempunyai calon presiden memanfaatkan dukungan kepada Jokowi berharap terhadap suara Golkar di Parlemen. Gojo adalah rebranding Golkar untuk Jokowi, yang selama ini identik sebagai kader PDI-P.

Ketiga, Gojo menyebabkan gangguan (disrupsi) terhadap lembaga Partai Golkar yang selama ini bekerja dengan pola organisasi dan struktural. Relawan Gojo yang tidak dibentuk dalam Musyawarah Nasional (Munas), namun dilaksanakan dengan swa-organisasi oleh kader Golkar. Maka dari itu, Gojo dimanfaatkan oleh caleg Golkar di Pemilu 2019 untuk memperkenalkan diri lebih awal kepada masyarakat.

Keempat, Gojo memudahkan Golkar melakukan kampanye lebih awal dari jadwal yang ditetapkan oleh KPU. Gojo yang berbasiskan relawan, tidak dibatasi dengan aturan KPU dan sistem yang ditetapkan oleh Facebook dan lainnya, karena mengunakan nama relawan sebagai media kampanye.

\section{DAFTAR PUSTAKA}

\section{Buku dan Jurnal:}

Andriadi, Fayakhun. Demokrasi Di Tangan Netizen: Tantangan dan Prospek Demokrasi Digital. Jakarta: Rmbook, 2016.

Arianto, Bambang. Fenomena Relawan Politik dalam Kontestasi Presidensial 2014, Jurnal Ilmu Sosial dan Ilmu Politik Volume 18, Nomor 2, (November 2014): 130-146.

\section{Kampanye Kreatif dalam}

Kontestasi Presidensial 2014. Jurnal Ilmu Sosial dan Ilmu Politik Volume 19, no. 1 (Juli 2015): 16-39.

Azwar, Rully Chairul. Politik Komunikasi Partai Golkar di Tiga Era: Dari Hegemonik ke Partai Berorientasi Pasar. Jakarta: Gramedia Widiasarana Indonesia, 2009.

Fukuyama, Francis. The Great Disruption: Hakikat Manusia dan Rekonstitusi Tatanan Sosial, Yogyakarta: Qalam, 2014.

Hanazaki, Yasuo. Pers Terjebak. Jakarta: Institute Studi Arus Informasi.1998.

Holik, Idham. Teknologi Baru Media Dan Demokratisasi Di Indonesia. Jurnal Makna, Volume 1. Nomor 2. (September 2010 Februari 2011).

Huntington, Samuel P.Political Order In Changing Societies. New Heaven and London, Yale University Press, 1968.

Jati, Wasisto Raharjo. Aktivisme Kelas Menengah Berbasis Media Sosial: Munculnya Relawan dalam Pemilu 2014, Jurnal Ilmu Sosial dan Ilmu Politik Volume 20, No. 2 (November 2016): $147-116$

Majalah Tempo, "Partai Pembonceng Jokowi", 18 Maret 2018.

Tandjung, Akbar. The Golkar Way: Survival Partai Golkar di Tengah Turbulensi Politik Era Trandisi. Jakarta: PT. Gramedia Pusataka Utama, 2007. 
Website:

Chaniago, Arifki. "Split Ticket Voting." 26 Maret 2019. Diakses 29 Juni 2020. https:// news.detik.com/kolom/d-4483650/splitticket-voting-di-pemilu-2019.

"Golkar akan Luncurkan Aplikasi Augmented Reality untuk Kampanyekan Jokowi.” 7 April 2019. Diakses 17 Mei 2021. https:// www.gatra.com/detail/news/408116Golkar-akan-Luncurkan-AplikasiAugmented-Reality-untuk-KampanyekanJokowi.

"Strategi Relawan Gojo yang Aktif Kampanyekan Jokowi di Medsos." Diakses 27 Juni 2020. https://www.gatra.com/ detail/news/372424-Strategi-RelawanGojo-yang-Aktif-Kampanyekan-Jokowi-diMedsos.

"Demi Jokowi untuk Dua Periode, Golkar Siapkan Relawan Siap Perang.” Diakses 18 Juli 2021. https://www.jawapos.com/ nasional/politik/19/02/2018/demijokowi-untuk-dua-periode-golkar-siapkanrelawan-siap-perang/.

Priasmoro, Muhammad Raditoyo. "Indikator Politik: Golkar Partai Paling Solid Dukung Jokowi-Ma'ruf." Diakses 27 Agustus 2021. https://www.liputan6.com/news/ $\mathrm{read} / 3858373 /$ indikator-politik-golkarpartai-paling-solid-dukung-jokowi-maruf.

"Golkar Beri Ruang yang Cukup Luas bagi Caleg Milenial.” Diakses 5 April 2021. https://m.mediaindonesia.com/politikdan-hukum/226944/golkar-beri-ruangyang-cukup-luas-bagi-caleg-milenial.

\section{Wawancara:}

Wawancara dengan Ahmad Doli Kurnia, Wakil Ketua Umum DPP Golkar, 18 Juli 2021, di Aplikasi Zoom (virtual).
Wawancara dengan Rizal Mallarangeng, Ketua Koordinator Relawan Golkar-Jokowi, 14 Juli 2021, di Aplikasi Zoom (virtual).

Wawancara dengan Ujang Komarudin, Pengamat Politik, 13 Juli 2021, di Aplikasi Zoom (virtual). 